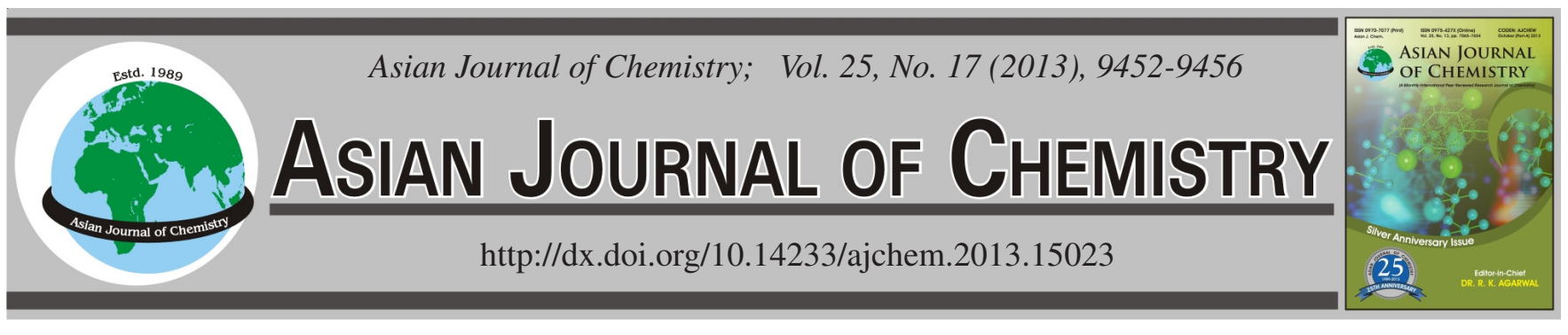

\title{
Liquid Chromatographic Determination of Neurotransmitter Serotonin from Human Cerebrospinal Fluid Using 2-Hydroxynaphtaldehyde as Derivatizing Reagent
}

\author{
INDRA PANJWANI", G.M. Arain and M.Y. KhUHAWAR
}

Institute of Advance Research Studies in Chemical Sciences Jamshoro, University of Sindh, Jamshoro, Pakistan

*Corresponding author: E-mail: icpanjwani@yahoo.com

\begin{abstract}
The reagent 2-hydroxy naphthaldehyde was used for the spectrophotometric and reversed phase HPLC separation and determination of glycine, lysine, octopamine, serotonin and tyramine. The derivatives formed were examined spectrophotomatrically for the effects of $\mathrm{pH}$, derivatizing reagent concentration and heating time in aqueous-methanolic solution. The derivatives indicated molar absorpitivity of 2.8 $\times 10^{3}-7.7 \times 10^{3} \mathrm{~L} \mathrm{~mol}^{-1} \mathrm{~cm}^{-1}$. The spectrophotometric calibration curves were observed within $1.0-20.0 \mu \mathrm{g} \mathrm{mL}{ }^{-1}$ at $\lambda_{\max } 420 \mathrm{~nm}$. The derivatives of 2-hydroxy naphthaldehyde were easily eluted and separated from Kromasil $100 \mathrm{C}-1810 \mu \mathrm{m}(25 \mathrm{~cm} \times 0.46 \mathrm{~cm}$ id $) \mathrm{column}$. The elution was carried out with methanol: water: acetonitrile and acetate buffer $(0.1 \mathrm{M})(\mathrm{pH} 6)(47: 25: 18: 10 \mathrm{v} / \mathrm{v} / \mathrm{v} / \mathrm{v})$ with a flow rate of $1 \mathrm{~mL} \mathrm{m^{-1 }}$ and UV detection was at $240 \mathrm{~nm}$. A number of amino acids and pharmaceutical additives were checked and did not interfere to the determination. The method was successfully applied for the determination of lysine from pharmaceutical preparation and serotonin and glycine from human cerebrospinal fluid. The analysis was further supported by standard addition method. The recovery of lysine from pharmaceutical preparation was $97.46 \%$ with RSD $2.8 \%$. Glycine and serotonin were determined from human cerebrospinal fluid and found 8.13-16.118 $\mu \mathrm{mol} \mathrm{L}^{-1}$ and 3.92-7.44 $\mathrm{nmol} \mathrm{L}^{-1}$ with RSD 1.6-3.3 and 1.4-3.6\%.
\end{abstract}

Key Words: HPLC, Lysine, Glycine, Serotonin, 2-Hydroxy naphthaldehyde, Cerebrospinal fluid.

\section{INTRODUCTION}

Neurotransmitter serotonin (5-hydroxytryptamine or 5-HT) is a monoamine neurotransmitter synthesized from the essential amino acid tryptophan in serotonergic neurons in the central nervous system and enterochromaffin cell in the gastrointestinal tract of animals including humans. Serotonin is implicated in number of physiological and behavioural functions such as control and regulation of affective behaviour, sleep, vigilance, reward, motor and cognitive functions as well as neuroendocrine functions, regulating food intake and body temperature. Serotonin is most important for the treatment of various disorders, particularly anxiety, depression, schizophrenia stroke, obesity, pain, hypertension, vascular disorders, migraine and nausea ${ }^{1,2}$. Glycine is inhibitory amino $\operatorname{acid}^{3}$ and act mainly in the spinal cord and in the brain system via the strychninesensitive glycine receptor. Glycine also exhibits a key role in the excitatory neuro-transminion in the N-methyl-D-aspartate receptor complex ${ }^{4,5}$. Lysine is an essential amino acid and is a building block of protein. Lysine is important for proper growth and lowers cholesterol. It helps to absorb the calcium ${ }^{6}$. It is therefore of interest to develop simple, rapid, specific and accurate method for the measurement of serotonin and glycine in biological samples and lysine from pharmaceutical preparation.

Various analytical methods for the determination of 5-HT, glycine and lysine and their metabolites have been reported; of these the most frequently used are pre or post column derivatization with high performance liquid chromatography (HPLC) $)^{7,8}$ with electrochemical or fluorescence detection ${ }^{9-14}$, gas chromatography $(\mathrm{GC})^{15,16}$, gas chromatography/mass spectrometry $(\mathrm{GCMS})^{17,18}$, capillary electrophoresis $(\mathrm{CE})^{5,19-21}$, capillary electrophoresis laser-induced fluorescence (CE-LIF) ${ }^{1}$, spectrophotometric ${ }^{22}$, polarographic ${ }^{23}$ and flow injection analy$\operatorname{sis}^{24}$. A number of derivatizing reagents have been reported for the HPLC determination of the amino acids and amines such as; ninhydrin ${ }^{25}$ densylchloride ${ }^{26}, 1,3$-oxadizole ${ }^{27}, o$ pathalaldehyde ${ }^{28}$, phenyl isocynate ${ }^{29}$ and 9-fluroenyl methyl chloroformate $^{30}$.

2-Hydroxy napthaldehyde has some resemblance to 2,3naphthaldicarboxaldehyde and does not require the addition of mercaptoethanol to block the second carbonyl group. 2-Hydroxy naphthaldehyde has been used as derivatizing reagent for the HPLC determination of 4-aminobutyric acid ${ }^{31}$, glutamine $^{32}$, tryptophan, histadine and methionine ${ }^{33,34}$ and dopamine $^{35}$. Present work examines the use of 2-hydroxy 
naphthaldehyde for the simultaneous separation of glycine, lysine, octopamine, tyramine and serotonin and determination of serotonin and glycine from cerebrospinal fluid samples and lysine from pharmaceutical preparation. The experimental conditions are optimized for derivatization and HPLC separation. Linearity, limit of detection (LOD), limit of quantitation and repeatability of quantitation is examined.

\section{EXPERIMENTAL}

A Hitachi 655A liquid chromatograph connected with variable wavelength UV monitor and Rheodyne 7125 injector was used. The responses of the UV detector were connected with computer with CSW-32 (Data Apex Ltd (C) 2001www.dataapex.com) software. A Kromasil 100 C-18 10 $\mu \mathrm{m}(25 \mathrm{~cm} \times 0.46 \mathrm{~cm}$ id $)$ was used through out the study. The spectrophotometric studies were carried out on double beam Hitachi 220 spectrophotometer (Hitachi (Pvt.) Ltd., Tokyo, Japan) with dual quartz cuvettes.

Serotonin creatinine sulfate, octopamine, tyramine, methanol (E. Merck, Germany) and acetonitrile (Fluka Switzerland) were used. Glycine, serine, leucine, valine, arginine (E. Merck Germany), phenylalanine, histadine, histamine, methionine, tyrosine, lysine, isolucine (Fluka Switzerland) were used. Sodium acetate, acetic acid, sodium bicarbonate, sodium carbonate, boric acid, borax, ammonium chloride, ammonia (23\%), acetonitrile, hydrochloric acid (37\%) (E. Merck Germany) were used. Freshly prepared doubly distilled water from all glass was used for HPLC studies. The buffer solutions in the $\mathrm{pH}$ range 1-10 at unit interval were prepared from the following: potassium chloride (1 M)-hydrochloric acid (0.1 M), pH 1-2, sodium acetate-acetic acid (1 M) pH 3-6, ammonium acetate-acetic acid (1 M) pH 7, boric acid-borax (1 M) pH 89 and ammonium chloride-ammonia solution (1 M) pH 10.

The cerebrospinal fluid (CSF) samples were collected from Neurosurgical ward Liaquat University of Medicine and Health Sciences, (LUMHS) Jamshoro with the verbal permission from patient/parents of patient. A part of cerebrospinal fluid was collected during surgical procedure ventriculopritoneal shunt with the verbal consent of the surgeon. The diagnosis of the patients was obtained from the records of the hospital with the permission of the duty doctor. The patient/attendant of the patient and duty doctor were informed the objectives of the research and they accepted to participate in the project.

Spectrophotometric procedure: Solution (0.1-1.0 mL) containing 10-200 $\mu \mathrm{g}$ glycine, lysine, tyramine, octopamine or serotonin was transferred separately to $10 \mathrm{~mL}$ volumetric flask and were added $1 \mathrm{~mL}$ acetate buffer $\mathrm{pH} 6$ and $2 \mathrm{~mL}$ reagent $\mathrm{HN}(0.1 \% \mathrm{w} / \mathrm{v}$ in methanol). The mixture was heated for 20 min on water bath at $75^{\circ} \mathrm{C}$ and the solution after cooling at room temperature was adjusted to the mark with methanol. The solutions were mixed well and absorbance was recorded against the reagent blank on Hitachi 220 spectrophotometer within 220-500 $\mathrm{nm}$.

HPLC procedure: Solution $(0.1-1.0 \mathrm{~mL})$ containing 8-100 $\mu$ g glycine, lysine, tyramine, octopamine and serotonin was transferred to $5 \mathrm{~mL}$ volumetric flask, was added $0.5 \mathrm{~mL}$ of acetate buffer $\mathrm{pH} 6,1 \mathrm{~mL}$ reagent 2-hydroxy naphthaldehyde $(0.1 \% \mathrm{w} / \mathrm{v}$ in methanol) and was warmed for $20 \mathrm{~min}$ at $75{ }^{\circ} \mathrm{C}$. The remaining procedure was followed as spectrophotometric procedure. The solution was mixed well and $20 \mu \mathrm{L}$ was injected on the column Kromasil 100 C-18 $10 \mu \mathrm{m}(25 \mathrm{~cm}$ $\times 0.46 \mathrm{~cm} \mathrm{id})$ and derivatives were eluted with mixture of methanol: water: aceto-nitrile and acetate buffer $(0.1 \mathrm{M}) \mathrm{pH} 6$ $(47: 25: 18: 10 \mathrm{v} / \mathrm{v} / \mathrm{v} / \mathrm{v})$ with a flow rate of $1 \mathrm{~mL} / \mathrm{min}$ and UV detection was at $240 \mathrm{~nm}$.

HPLC determination of serotonin and glycine from cerebrospinal fluid (CSF) samples: Cerebrospinal fluid samples (2-5 mL) were added equal volumes of methanol and centrifuged at $12000 \mathrm{rpm}$ for $15 \mathrm{~min}$. The supernatant layer was collected and reagents were added as HPLC analytical procedure. The solution was heated on water bath in nitrogen atmospheres near to dryness and contents were dissolved in methanol and final volume was adjusted to $1 \mathrm{~mL}$ with methanol. The solution $20 \mu \mathrm{L}$ was injected on the column and derivatives were eluted as HPLC procedure. The concentration of serotonin and glycine in cerebrospinal fluid was evaluated from an external calibration curve, prepared from standard solution following the same procedure using regression equation $\mathrm{Y}=\mathrm{ax}+\mathrm{b}$.

HPLC determination of serotonin and glycine from cerebrospinal fluid samples using standard addition technique

The cerebrospinal fluid sample $(2-5 \mathrm{~mL})$ was treated as HPLC determination from cerebrospinal fluid. Supernatant liquid was separated and divided into two equal portions (A and B). The fraction B was added glycine 8 or $5 \mu \mathrm{g}$ and serotonin 8,6 or $5 \mu \mathrm{g}$ and both the solution A and B were treated as HPLC determination from cerebrospinal fluid. The final volume was adjusted up to $1.0 \mathrm{~mL}$ with methanol. The amount of glycine and serotonin in fraction A was evaluated from standard calibration curve and in fraction B was calculated from average increase in the response with added standard.

Analysis of lysine from pharmaceutical preparation: Five tablets of lysine (Holland Barrett, Netherland) containing $1000 \mathrm{mg} /$ tablet lysine were crushed to powder and an amount $1.5018 \mathrm{~g}$ corresponding to one tablet was dissolved in water. The solution was filtered and volume made up to $100 \mathrm{~mL}$ with deionized distilled water. The solution $(1.0 \mathrm{~mL})$ was further diluted to $100 \mathrm{~mL}$ and solutions $0.6 \mathrm{~mL}$ and $1.0 \mathrm{~mL}$ were taken and HPLC procedure was followed as described. The quantitation was made from external calibration curve prepared from standard solutions using linear regression equation $\mathrm{Y}=\mathrm{ax}+\mathrm{b}$.

Analysis of lysine from pharmaceutical preparation by standard addition: Five lysine tablets (Holland Barrett, Netherlands) were processed and aqueous solution were prepared as analysis of pharmaceutical preparation. Three solutions of $1 \mathrm{~mL}$ each from final prepared solution were transferred to $10 \mathrm{~mL}$ volumetric flasks. Two solutions were added lysine standards corresponding to 2.0 and $4.0 \mu \mathrm{g} \mathrm{mL}^{-1}$ at final concentration. All the solutions were processed as HPLC procedure as described. The quantitation was made from linear calibration and from the average increase in response $(n=5)$ with added standards.

\section{RESULTS AND DISCUSSION}

The reagent 2-hydroxy-1-naphthaldehyde (HN) reacts with primary amino group containing compounds to form 
highly stable Schiff bases ${ }^{31-35}$. The reaction of glycine and serotonin with 2-hydroxy naphthaldehyde were examined in aqueous methanolic solution (Fig. 1). The reactions initially were monitored spectrophotometrically to optimize the reaction condition. The conditions, which gave maximum responses (absorbance at particular wave length) was considered as optimal. The $\mathrm{pH}$ was varied within the range $1-10$ at unit interval. The optimum responses were obtained within $\mathrm{pH}$ 5-7 with maximum pH 6 and acetate buffer pH 6 was selected (Fig. 2). Heating time at $75^{\circ} \mathrm{C}$ was varied from 5-35 min with an interval of $5 \mathrm{~min}$. The maximum response was measured by heating tyramine and lysine for $10 \mathrm{~min}$, glycine $15 \mathrm{~min}$, octopamine and serotonin for $20 \mathrm{~min}$, thus the warming time for derivatization was fixed at $20 \mathrm{~min}$ (Fig. 3). The amount of derivatizing reagent $\mathrm{HN}$ was varied between $1-4 \mathrm{~mL}$ at an interval of $1 \mathrm{~mL}$ at a concentration of $0.1 \%(\mathrm{w} / \mathrm{v}$ in methanol) and optimal response was obtained with $2 \mathrm{~mL}$ (Fig. 4). The derivatives once formed were highly stable and did not show any change in absorbance up to $12 \mathrm{~h}$.

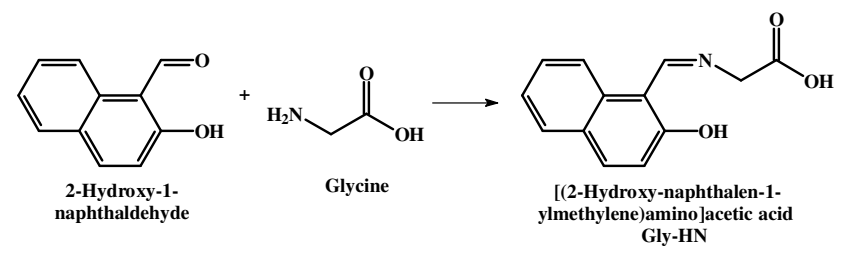

(a)

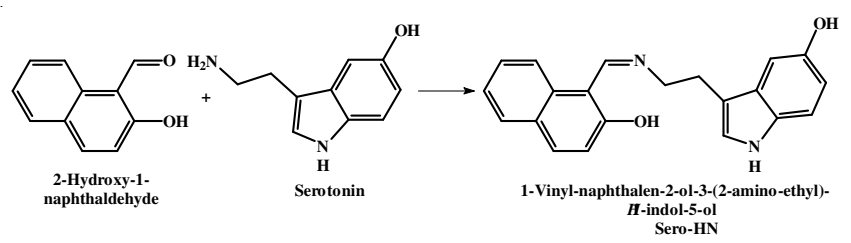

(b)

Fig. 1. Chemical reactions of 2-hydroxy-1-naphthaldehyde (HN) with (a) glycine (Gly-HN) and (b) serotonin (Sero-HN)

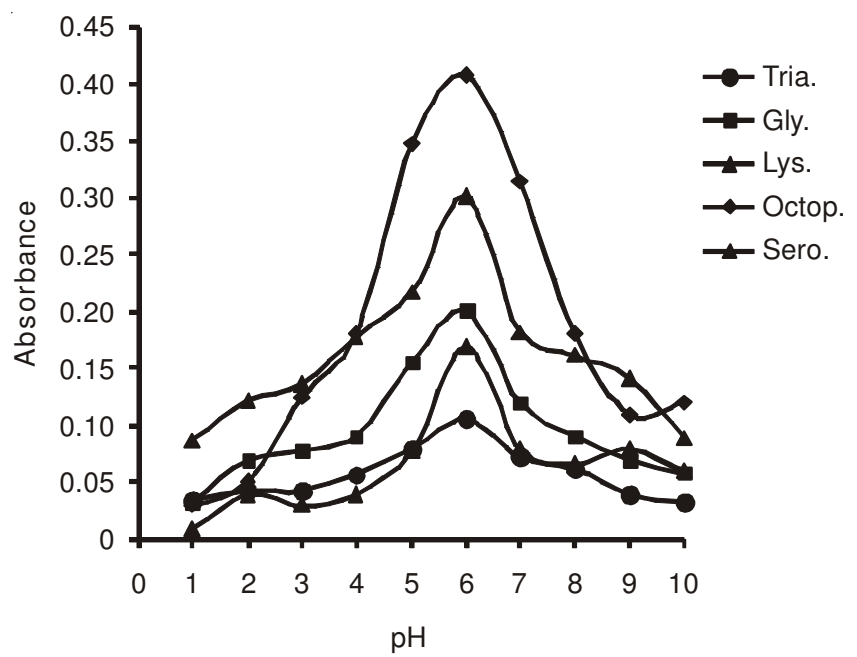

Fig. 2. Effect of $\mathrm{pH}$ on the absorbance of 2-hydroxy-1-naphthaldehyde derivatives

At optimized conditions derivatives indicated reasonable sensitivity with molar absorpitivities within $2.8 \times 10^{3}-7.7 \times$ $10^{3} \mathrm{~L} \mathrm{~mol}^{-1} \mathrm{~cm}^{-1}$ at $\lambda_{\max } 420 \mathrm{~nm}$. However glycine and serotonin with 2-hydroxy-1-naphthaldehyde indicated molar absorpitivity

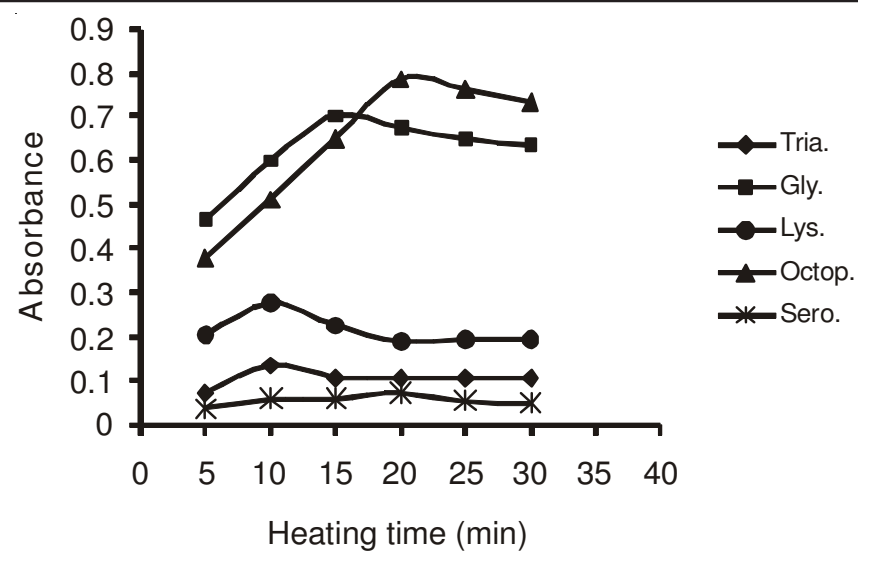

Fig. 3. Effect of heating time on the 2-hydroxy-1-naphthaldehyde derivatives

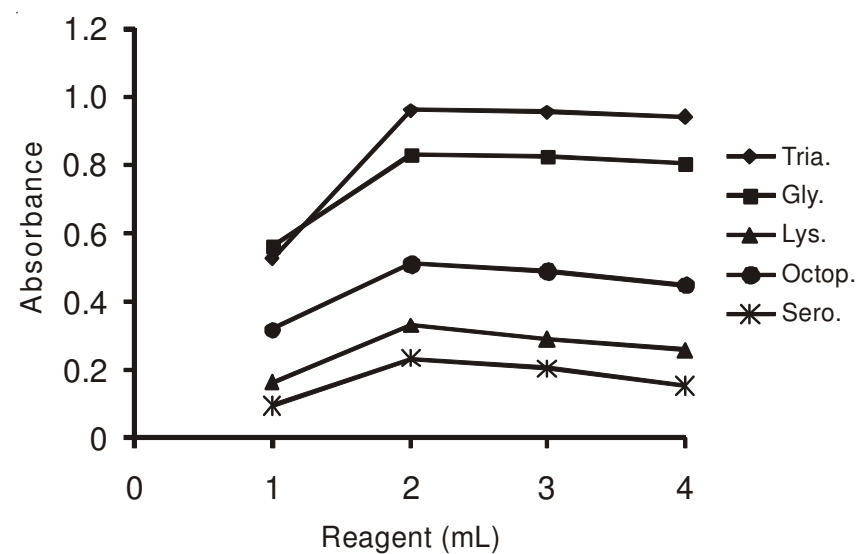

Fig. 4. Effect of volume of the reagent on the 2-hydroxy-1-naphthaldehyde derivatives

$2.8 \times 10^{3}$ and $7.7 \times 10^{3} \mathrm{~L} \mathrm{~mol}^{-1} \mathrm{~cm}^{-1}$ and obeyed LambertBeer's law with 1.25-10 and 0.8-10 $\mathrm{gg} \mathrm{L}^{-1}$ with coefficient of determination $\left(r^{2}\right) 0.9964$ and 0.9973 , respectively (Table-1).

To increase the selectivity of the determination at optimized spectrophotometric conditions HPLC was investigated. Serotonin derivative of 2-hydroxy-1-naphthaldehyde eluted from Kromasil 100C-18 column and separated from the excess of the reagent 2-hydroxy-1-naphthaldehyde. Glycine, lysine, octopamine and tyramine also completely separated simultaneously when eluted with methanol: water: acetonitrile: and acetate buffer $(0.1 \mathrm{M}) \mathrm{pH} 6(47: 25: 18: 10 \mathrm{v} / \mathrm{v} / \mathrm{v} / \mathrm{v})$ with flow rate of $1 \mathrm{~mL}$ $\mathrm{min}^{-1}$ and UV detection was at $240 \mathrm{~nm}$ (Fig. 5). The spectrophotometric detector response could be measured at $420 \mathrm{~nm}$, but because of better UV sensitivity at $240 \mathrm{~nm}$, was selected. Repeatability for the elution of serotonin, glycine, octopamine, tyramine and lysine derivatives in terms of average peak height and retention time $(\mathrm{n}=5)$ were observed with RSD within 1.8-3.4\%.

Linear calibration curves for glycine, lysine, octopamine, serotonin and tyramine were obtained with 1.25-10, 1-10, 0.86, 0.8-10 and 0.8-4.7 $\mu \mathrm{g} \mathrm{mL}^{-1}$ with coefficient of determination $\left(r^{2}\right)$ 0.9964, 0.9987, 0.9979, 0.9973 and 0.9966, respectively. Detection limits were measured as three times back ground noise and were obtained $0.42,0.33,0.26,0.26$ and $0.26 \mu \mathrm{g}$ $\mathrm{mL}^{-1}$ corresponding to $8.33,6.66,5.33,5.33$ and $5.33 \mathrm{ng}$ injection $^{-1}(20 \mu \mathrm{L})$ of glycine, lysine, octopamine, serotonin and tyramine, respectively (Table-2). Limit of quantitative measured as signal to noise ratio 10:1 were obtained 1.25, 
TABLE-1

QUANTITATIVE SPECTROPHOTOMETRIC DATA OF AMINO ACIDS DERIVATIVES OF 2-HYDROXY-NAPHTHALDEHYDE

\begin{tabular}{|c|c|c|c|c|c|c|}
\hline Amino acids & $\begin{array}{c}\mathrm{pH} \text { of max: } \\
\text { derivatization }\end{array}$ & $\begin{array}{l}\text { Effect of heating } \\
\text { time (min) }\end{array}$ & $\lambda_{\max }(\mathrm{nm})$ & $\begin{array}{c}\text { Calibration range }(\mu \mathrm{g} \\
\left.\mathrm{mL}^{-1}\right)\end{array}$ & $\begin{array}{c}\text { Molar absorpitivity } \\
\left(\mathrm{L} \mathrm{mol}^{-1} \mathrm{~cm}^{-1}\right)\end{array}$ & $r^{2}$ \\
\hline Tyramine & 6 & 10 & 420 & $3-15$ & $4.3 \times 10^{3}$ & 0.9958 \\
\hline Glycine & 6 & 15 & 420 & $2.5-20$ & $2.8 \times 10^{3}$ & 0.9976 \\
\hline Lysine & 6 & 10 & 420 & $4-16$ & $3.7 \times 10^{3}$ & 0.9974 \\
\hline Octopamine & 6 & 20 & 420 & $1-12$ & $5.9 \times 10^{3}$ & 0.9927 \\
\hline Serotonin & 6 & 20 & 420 & $1-8$ & $7.7 \times 10^{3}$ & 0.9963 \\
\hline
\end{tabular}

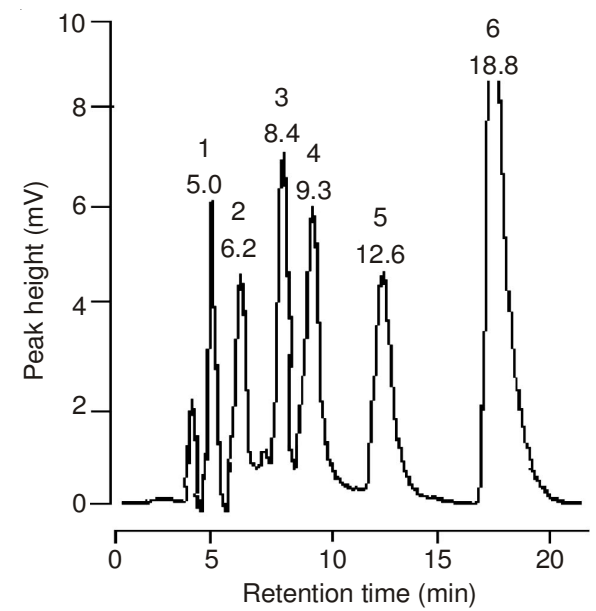

Fig. 5. HPLC separation of derivatives of HN, (1) Glycine, (2) Lysine, (3) Tyramine, (4) Octopamine (5) Serotonin (6) HN. Column Kromasil $100 \mathrm{C}-18,10 \mu \mathrm{m}(25 \mathrm{~cm} \times 0.46 \mathrm{~cm}$ id $)$, eluant methanol: water: acetonitrile: and acetate buffer $(0.1 \mathrm{M}) \mathrm{pH} 6(47: 25: 18: 10 \mathrm{v} / \mathrm{v} / \mathrm{v} / \mathrm{v})$ with flow rate of $1 \mathrm{~mL} \mathrm{~min}^{-1}$ and UV detection was at $240 \mathrm{~nm}$

TABLE-2

QUANTITATIVE HPLC DATA OF AMINO-ACIDS USING 2HYDROXYNAPHTHALDEHYDE AS DERIVATIZING REAGENT

\begin{tabular}{cccc}
\hline Amino acid & $\begin{array}{c}\text { Calibration } \\
\text { range }\left(\mu \mathrm{gmL}^{-1}\right)\end{array}$ & $\begin{array}{c}\text { Detection limit ng } \\
\text { injection }^{-1}(20 \mu \mathrm{L})\end{array}$ & $\mathrm{r}^{2}$ \\
\hline Glysine & $1.25-10$ & 8.33 & 0.9964 \\
Lysine & $1-10$ & 6.66 & 0.9987 \\
Octopamine & $0.8-6$ & 5.33 & 0.9979 \\
Serotonin & $0.8-10$ & 5.33 & 0.9973 \\
Tyramine & $0.8-4.7$ & 5.33 & 0.9966 \\
\hline
\end{tabular}

$1.0,0.8,0.8,0.8 \mu \mathrm{g} \mathrm{mL} \mathrm{m}^{-1}$ for glysine, lysine, octopamine, serotonin and tyramine, respectively. The amino acids cystine methonine, phenylalanine, serine, aspergine, tyrosine, cysteine, arginine, aspartic acid, valine, isolusine and glutamic acid when added at the same concentration did not interfere in the deter- mination of glycine and serotonin and lysine. Similarly pharmaceutical additives methylparabin, propylparabin, gum acacia, manitol, lactose, fructose, glucose, lactose, sodium chloride, sodium laryl sulphate, methyl hydroxypropyl cellulose, magnesium stearate and stearic acid were added at least twice the concentration of analyte did not affect the determination of lysine, glycine and serotonin. Five test solutions within the calibration range of lysine, glycine and serotonine were analyzed and relative errors were obtained $\pm 2.3-5.0 \%$.

Lysine tablets used as dietary source were analyzed for the contents of the lysine in the tablets. The amount found was $974.6 \mathrm{mg} /$ tablet with RSD $2.8 \%$. The value agreed with the labeled value of $1000 \mathrm{mg} /$ tablet. The lysine tablet solution was spiked with, 2.0 and $4.0 \mu \mathrm{g} \mathrm{mL} \mathrm{m}^{-1}$ standard solutions and a similar chromatogram was obtained with an increase in the response (peak height/peak area) corresponding to added standards with recovery calculated, 97.0 and $98.2 \%$ with RSD $1.8 \%$ and $2.4 \%(n=5)$ (Table-4). Five human cerebrospinal fluid samples were collected from neurosurgical ward of Liaquat University of Medicine and Health Sciences (LUMHS), patient suffering from meningitis, cerebral malaria, headache fever and fits and were analyzed for glycine and serotonin content and the amounts found were 8.13-16.12 $\mu \mathrm{mol} \mathrm{L}^{-1}$ of glycine with RSD 1.6-3.3\% and 3.92-7.44 $\mathrm{nmol} \mathrm{L}^{-1}$ of serotonin with RSD of 1.4-3.6 \% (Fig. 6). The maximum amount of glycine $16.12 \mu \mathrm{mol} \mathrm{L}{ }^{-1}$ was observed from the patient suffering from cerebral malaria and minimum $8.13 \mu \mathrm{mol} \mathrm{L^{-1 }}$ from the patient suffering from meningitis. However the maximum amount of serotonin $7.44 \mathrm{nmol} \mathrm{L}^{-1}$ was observed from the patient suffering from headache fever and minimum $3.92 \mathrm{nmol}$ $\mathrm{L}^{-1}$ was found from the patient suffering from meningitis. Cerebrospinal fluid samples (1, 3 and 5) were added calculated amounts 8 and $5 \mu \mathrm{g} \mathrm{mL}^{-1}$ of glycine and 8,6 and $5 \mu \mathrm{g} \mathrm{mL}^{-1}$ of serotonin, respectively and the results obtained correlated with observed values by calibration with RSD 1.4-3.1 and 1.7-2.7 \%,

TABLE-3

HPLC ANALYTICAL RESULTS OF AMINO ACIDS FROM CSF SAMPLES USING HN AS DERIVATIZING REAGENT

\begin{tabular}{|c|c|c|c|c|}
\hline Subject $(\mathrm{M} / \mathrm{F})$ & Age (years) & Disease & $\begin{array}{l}\text { Determination of glycine } \\
\left.(\mu \mathrm{mol} \mathrm{L})^{-1}\right)(\text { RSD } n=3)\end{array}$ & $\begin{array}{l}\text { Determination of serotonin } \\
\left(\mathrm{nmol} \mathrm{L}{ }^{-1}\right)(\mathrm{RSD}=3)\end{array}$ \\
\hline $\mathrm{F}$ & 35 & Meningitis & $15.452(3.2)$ & $4.60(3.6)$ \\
\hline M & 18 & Meningitis & $8.125(2.4)$ & $3.92(2.4)$ \\
\hline M & 17 & Cerebral Malaria & $16.118(2.8)$ & $4.43(2.8)$ \\
\hline M & 46 & Headache fever & $13.721(1.6)$ & $7.44(1.4)$ \\
\hline $\mathrm{M}$ & 2 & Fits & $12.122(3.3)$ & $5.51(3.2)$ \\
\hline \multicolumn{5}{|c|}{ By standard addition technique } \\
\hline Subject (M/F) & Age (years) & Disease & $\begin{array}{l}\text { Determination of glycine } \\
\left.(\mu \mathrm{mol} \mathrm{L})^{-1}\right)\end{array}$ & $\begin{array}{l}\text { Determination of serotonin } \\
\left.(\mathrm{nmol} \mathrm{L})^{-1}\right)\end{array}$ \\
\hline $\bar{F}$ & 35 & Meningitis & $14.896(96.4)^{*}(3.1) * *(8)^{* * *}$ & $4.51(98.07 \%)^{*}(2.1)^{* *}(8)^{* * *}$ \\
\hline M & 17 & Cerebral malaria & $15.763(97.8)^{*}(1.4) * *(5)^{* * *}$ & $4.29(96.92 \%)^{*}(1.7)^{* *}(6)^{* * *}$ \\
\hline $\mathrm{M}$ & 2 & Fits & $11.796(97.31) *(2.4)^{* *}(5) * * *$ & $5.454(98.96 \%) *(2.7) * *(5) * * *$ \\
\hline
\end{tabular}




\begin{tabular}{ccccccc}
\hline \multicolumn{8}{c}{ TABLE-4 } \\
ANALYSIS OF LYSINE FROM PHARMACEUTICAL PREPARATION USING \\
2-HYDROXY NAPHTHALDEHYDE AS DERIVATIZING REAGENT
\end{tabular}

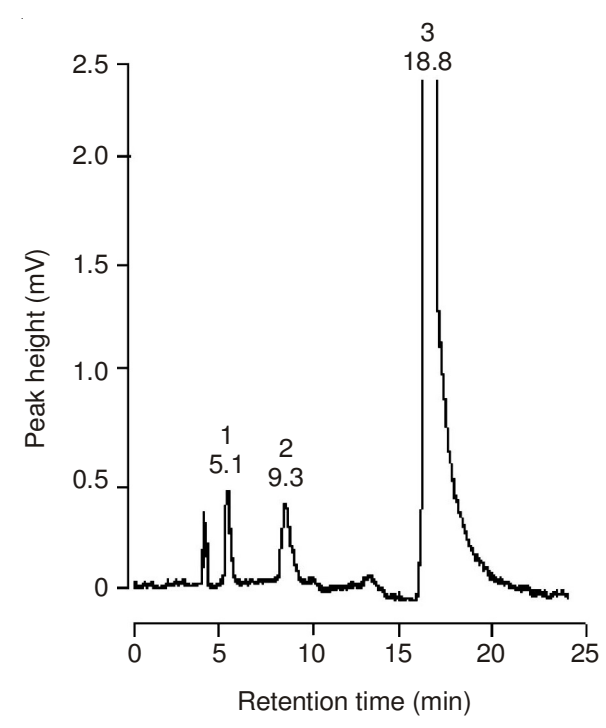

(a)

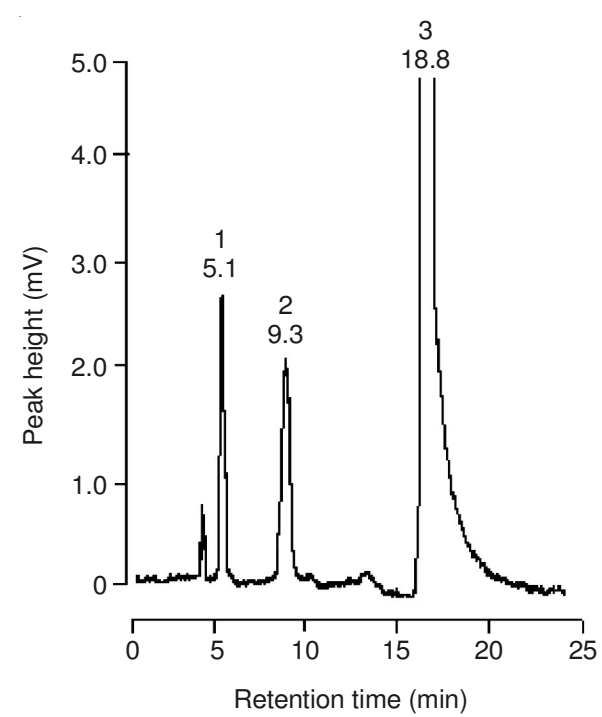

(b)

Fig. 6. HPLC response of (a) HPLC response from cerebrospinal fluid samples (b) HPLC response from cerebrospinal fluid samples after spiking with Glycine $8.0\left(\mu \mathrm{g} \mathrm{mL} \mathrm{mL}^{-1}\right)$ serotonin $6.0\left(\mu \mathrm{g} \mathrm{mL} \mathrm{m}^{-1}\right)$. Chromatographic conditions as Fig. 5

respectively. The results of glycine in cerebrospinal fluid were similar to those already described ${ }^{5,36}$ and value of serotonin in cerebrospinal fluid.

\section{Conclusion}

An analytical method has been developed for the accurate, sensitive and selective determination of serotonin and glycine in cerebrospinal fluid and lysine from pharmaceutical preparation. The detection limit for serotonin and glycine were 5.33 and $8.33 \mathrm{ng}$ injection ${ }^{-1}(20 \mu \mathrm{L})$. A number of amines, amino acids and pharmaceutical additives examined, did not affect the determination of serotonin and glycine. The method was successfully applied for the determination of serotonin, glycine and lysine from human cerebrospinal fluid and lysine from pharmaceutical preparation.

\section{REFERENCES}

1. D.A. Roman, A.S. Carretero, C.C. Blanco and A.F. Gutierrez, Biomed. Chromatogr., 18, 422 (2004).

2. T. Yoshitake, J. Kehr, K. Todoroki, H. Nohta and M. Yamaguchi, Biomed. Chromatogr., 20, 276 (2006).

3. G.E. Nilson and P.L. Lutz, Am. J. Physiol., 261, R32 (1991).

4. D.M. Lambert, M. Geurts, G.K. Seriba, J.H. Poupaert and P. Dumont, J. Pharm. Belg., 50, 194 (1995).

5. A. Zinella, S. Sotgia, E. Pisanu, B. Scanu, M. Sanna, M.F. Usai, R. Chessa, L. Deiana and C. Carru, Anal. Bioanal. Chem., 398, 1973 (2010).

6. M. Dousa, J. Brichac, P. Gibala and P. Lehnert, J. Pharm. Biomed. Anal., 54, 972 (2011).

7. B.W. Boyd, S.R. Witowski and R.T. Kennedy, Anal. Chem., 72, 865 (2000).

8. D.V. Augusti, F. Carazza, R. Augusti, W.A. Tao and R.G. Cooks, Anal. Chem., 74, 3458 (2002).

9. R. Kvetnansky, K. Pacak, D. Tokarev, J. Jelokova, D. Jezova and M. Rusnak, Neurochem. Res., 22, 995 (1997).

10. M.H. Mills, D.C. Finlay and P.R. Hadad, J. Chromatogr., 564, 93 (1991).

11. A.T. Wood and M.R. Hall, J. Chromatogr. B: Biomed. Sci. Appl., 744, 221 (2000).

12. T. Yoshitake, J. Kehr, K.T. Todoroki and M. Yamaguchi, Biomed. Chromatogr., 20, 267 (2006).

13. K.E. Hubbard, A. Wells, T.S. Owens, M. Tagen, C.H. Fraga and C.F. Stewart, Biomed. Chromatogr., 24, 626 (2010).

14. A.C.C.L. Martins and M.B.A. Gloria, Food Chem., 118, 529 (2010).

15. P. Husek, J. Chromatogr. B: Biomed. Sci. Appl., 615, 1 (1993).

16. K.-R. Kim, J.-H. Kim, C.-H. Oh and T.J. Mabry, J. Chromatogr. A, 605, 241 (1992).

17. J.W. Commissiong, J. Neurochem., 41, 1313 (1983).

18. L.U. Sneddon, A.C. Taylor, F.A. Huntingford and D.G. Watson, J. Exp. Biol., 203, 537 (2000).

19. P.L. Chang, T.C. Chiu and H.T. Chang, Electrophoresis, 27, 1922 (2006).

20. C. Parata, P. Bonnafous, N. Fraysse, M. Treilhou, V. Poinsot and F. Conderc, Electrophoresis, 22, 4129 (2001).

21. V. Poinsot, P. Gavard, B. Feurer and F. Couderc, Electrophoresis, 31, 105 (2010).

22. A.M. EL-Brashy and S.M. AL-Ghannam, Pharm. World Sci., 17, 54 (1995).

23. P.J. Vandeberg and D.C. Johnson, Anal. Chem., 65, 2713 (1993).

24. C. Mayer, A. Franer, T. Schalkhammar and F. Pitterner, Anal. Biochem., 268, 110 (1999).

25. M. Rubenstein, S. Chen-Klang, S. Stein and S. Undenfriend, Anal. Biochem., 95, 117 (1979).

26. M.A. Sanz, G. Castillo and A. Hernandez, J. Chromatogr. A, 719, 195 (1996).

27. A. Alegria, R. Barbera, R. Farre, M. Ferres, M.J. Lagarda and J.C. Lopez, J. Chromatogr. A, 721, 83 (1996).

28. R. Soto-Otero, E. Mendez-Alvarez, J. Galan-valiente, E. Aguilar-Veiga and G. Sierra-Marcuno, Biomed. Chromatogr., 8, 114 (1994).

29. L.E. Lavi, J.S. Holcenberg, D.E. Code and J. Jolivet, J. Chromatogr. Biomed. Appl., 50, 155 (1986).

30. D. Fekkes, J. Chromatogr. A, 682, 3 (1996).

31. M.Y. Khuhawar and A.D. Rajper, J. Chromatogr. B, 788, 413 (2003).

32. M.Y. Khuhawar and A.D. Rajper, Chromatographia, 58, 479 (2003).

33. A.M. Al-Brashy and S.M.Al-Ghannam, Analyst, 122, 147 (1997).

34. S.A. McClimlock, E.C. Purdy and S.N. Young, Anal. Chim. Acta, 166, 171 (1985).

35. A.D. Rajper, G.M. Arain, F.M.A. Rind and M.Y. Khuhawar, Asian J. Chem., 19, 4817 (2007).

36. M. Garseth, L.R. White and J. Aasly, Neurochem. Int., 39, 111 (2001). 